\title{
EUANGELIZESTHAI (OM TE EVANGELISEER) EN VERWANTE WOORDE IN DIE NT
}

M. A. Kruger

\section{INLEIDING}

Daar is meer as dertig woorde wat in die Bybel gebruik word om die oorbring van die evangelie te beskryf (Gitari 1975:1123, Friedrich ThWNT II : 720; III : 703). Sommige van hierdie woorde is feitlik sinoniem. Ander is nuanseringe in ' $n$ wyer begrip. Hierdie nuanseringe word dikwels met preposisies in saamgestelde werkwoorde uitgedruk. So word diamarturesthai 'n bepaalde beklemtoning van marturein.

Ons gaan veral aandag gee aan euangelizesthai, kērussein met die selfstandige naamwoord euangelion, didaskein, mathēteuein, martus en die groep rondom hom, diamarturesthai en aan elenchein wat nie in hierdie groep val nie, maar onontbeerlik is om 'n duidelike begrip van euangelizesthai te kry.

\section{EUANGELIZESTHAI (Om te evangeliseer)}

Gebruik in die NT

Euangelizesthai word deur Matteus 1 keer gebruik, deur Lukas in sy Evangelie en in Handelinge 25 keer, deur Paulus $21 \mathrm{keer}$, in Hebreërs 2 keer, in 1 Petrus 3 keer en in Openbaring 2 keer. Dit is opmerklik dat uit die 54 keer dit glad nie in die Evangelie volgens Johannes of in sy briewe gebruik word nie. Ook in die Evangelie volgens Markus word dit nie gebruik nie. Friedrich (ThWNT II : 717) bewcer dat euangelizesthai 'n dramatiese, dinamiese proklamasie van die tyd van verlossing beteken en dat dit nie inpas by die sogenaamde gerealiseerde eskatologie van die Evangelie volgens Johannes nie. In die gebruik van euangelizesthai sou dan volgens Friedrich die sogenaamde Messias-geheim nog bewaar word, maar die Evangelie volgens Johannes sou dan 'n later fase van kalme vervulling reflekteer. Hierdie standpunt van Friedrich hoef nie aan vaar te word nie. Die oplossing is veel eenvoudiger. Die geval van Markus bewys dit. Markus gebruik ook nie euangelizesthai nie. Maar hy bring dieselfde dinamiese verkondiging uit deur kērussein saam met die selfstandige naamwoord euangelion. Vir sover Johannes 'n besondere eie klem lê op dieselfde saak van evangelisering gebruik hy veral weer marturein. Slegs in die Evangelie volgens Johannes word marturein al 33 keer gebruik. Die inhoud van hierdie getuienis is dat Jesus die Seun van God is (Strathmann ThWNT IV: $513,514)$.

Deur wie is ge-evangeliseer?

Dit blyk dat die handelende persone 'n groot verskeidenheid is: Jesus (Mat. 11:5; Luk. 4:18; $4: 43 ; 7: 22 ; 8: 1 ; 20: 1$ ); Gabriël (Luk. 1:19); die engel aan die herders (Luk. 2:10); die engel in die middel van diie lug (Openb. 14:6); Johannes die Doper (Luk. $3: 18$ ); die Twaalf (Lukas 9:6); Petrus en die apostels (Handelinge $5: 42$ ); die wat verstrooi is deur die vervolging (Hand $8: 4$ ); 
Filippus (Hand 8: 12; 8:35; 8:40); Petrus en Johannes (Hand $8: 25$ ); God (Hand 10:36; Ef. 2:17; Openb. 10:7); Sipriese en Sirenese manne (Hand 11:20); Paulus en Barnabas (Hand 13:32; $14: 7 ; 14: 15 ; 15: 35$ ); Lukas, Paulus en ander (Hand 16:10); Paulus (Hand 17:18; Rom. 1:15; 1 Kor. $1: 17$; 1 Kor 9:16, $18: 2$ Kor 11:7); die wat gestuur is om te preek (Rom. 10:15 in aansluiting by Jesaja $52: 7$ ); 'n engel wat dit moontlik sou kon probeer (Gal. 1:8) en Timoteüs (1 Tes. $3: 6$ ).

Wie word ge-evangeliseer.

Hier is byna net so 'n ruim verskeidenheid. Daar is besondere gevalle, maar dit word gou duidelik dat die hele wêreld gevangeliseer moet word. Dit begin met Jesus se optrede onder sy eie volk en gaan later voort deur die arbeid van die apostels en die kerk na elkeen wat nog nie ge-evangeliseer is nie.

Die wat ge-evangeliseer word of moet word, is die armes (Mat. $11: 5$; Luk. $4: 18 ; 7: 22$ ); Sagaria (Luk. $1: 19$ ); herders en die hele volk (Luk. 2:10); die volk, tollenaars, soldate, Abraham se kinders (Luk. 3:3-18); stede en dorpe (Luk. 4:43; 8:1; $9: 6$; Hand 8:40); dorpe van Samaria (Hand 8:25); stede van Likaonië, Listre, Derbe (Hand 14:7, 15); die kamerling van Etiopië (Hand $8: 35$ ); Jode (Hand 13:32); mense van Masedonië (Hand 16:10); Ateners (Hand 17:18); die gemeente van Rome (Rom 1:15); diegene aan wie Christus nie genoem is nie (Rom. 15:20 vgl. 2 Kor. $10: 16$ ); die Korintiërs (1 Kor. $15: 1,2 ; 2$ Kor. $11: 7$ ); die Galasiërs (Gal. 1:8, 9; 4:13); die wat ver is (Ef $2: 17 ; 3: 8$ ); Paulus-hulle ( 1 Tes. 3:6); die Kerk van die NT en OT (Hebr. 4:2; 4:6); die lesers van Petrus se briewe ( 1 Pet. $1: 12$ ); die dode (1 Pet. 4:6); profete (Openb. 10:7) en die bewoners van die aarde (Openb. $14: 7)$.

Wat word ge-evangeliseer?

Evangeliseer is 'n proses waarin gekommunikeer word. In die proses dra die evangeliserende iets oor aan hom wat ge-evangeliseer word. Wat is dit wat oorged ra word?

Vir Sagaria is dit dat hy en Elisabet 'n seun sal hê (Luk. 1:19); aan die herders is dit 'n groot blydskap wat as inhoud het die geboorte van die Redder (Luk. 2:10-11); in Luk. $3: 3-17$ is dit die inhoud van Johannes die Doper se prediking en nog baie ander dinge wat nie daar opgeskryf is nie; dis die Koninkryk (Luk 4:43; $8: 1$; 16: 16; Hand. $8: 12$ ); dis Christus Jesus (Hand $5: 42 ; 8: 12 ; 8: 35$; $10: 36 ; 11: 20 ; 17: 18$ ); dis die onnaspeurlike rykdom van Christus (Ef. $3: 8$ ); dis die woord (Hand. $8: 4 ; 15: 35 ; 1$ Pet. $1: 25$ ); dis vrede deur Jesus Christus (Hand. 10:36; Ef $2: 17$ ); dis die belofte wat in die opstanding vervul is (Hand $13: 32$ ); dis die evangelie (1 Kor. $9: 18$; 1 Kor. $15: 1$; 2 Kor. $11: 7$; Gal. $1: 11$ ); dis die geloof (Gal 1:23); dis 'n goeie berig van Tessalonika af (1 Tes. 3:6).

Samevatting oor euangelizesthai

Euangelizesthai vertoon drie betekenis-skakerings:

* Om Jesus (met al die weldade wat ons van Hom ontvang) mee te deel aan iemand wat Hom nie ken en nog nie in Hom glo nie. 
** Om mense wat reeds in Jesus glo verder op te bou in die geloof.

*** Om 'n goeie boodskap van 'n ander (ons kan byna sê meer sekulêre) aard aan iemand mee te deel.

Verreweg die meeste kere word dit in die eerste betekenis gebruik, dws om Jesus as Verlosser te verkondig. In enkele gevalle (bv. Rom. 1:15) word dit in die tweede sin gebruik en in uitsonderlike gevalle in die derde betekenis. (1 Tes. 3:6 waar Timoteüs 'n goeie tyding oor dié toestand in die gemeente van Tessalonika bring, is so 'n geval).

Bosch (1979:21) is dus reg as hy sê dat evangelisasie ('n mens wil liewer sê: om te evangeliseer MAK) altyd heel spesifiek beteken die oorskryding van ongeloof na geloof. Die kern is dat dit altyd die uitnodiging tot dissipelskap bevat. (Hier word die gevalle van die tweede en derde betekenisse hierbo genoem, natuurlik nie nou ingesluit nie).

Evangeliseer is om te saai

Dit is die aankondiging van die euangelion of goeie nuus. Evangeliseer moet nie beskrywe word vanuit resultate nie (Stott $1981: 53$ ), maar vanuit die oogpunt van die arbeid van die saaier.

\section{KERUSSEIN TO EUANGELION}

Dodd (1936:10) sê dat kērussein sonder meer as sinoniem gebruik kan word vir euangelizesthai. Daar is egter in die NT ook gevalle waar kērussein anders gebruik word as die hoofbetekenis van euangelizesthai, bv. Markus 1:4; Rom. 2:21. Dan kom dit ooreen met die ander gebruike. Ook Friedrich (ThWNT II: 718) sê dat die twee woorde sinoniem gebruik word. Lukas en Paulus gebruik euangelizesthai baie: 46 uit die 54 keer, teenoor een keer van Matteus en glad nie deur Markus nie. Matteus en Markus gebruik kērussein meer, nl. 23 keer uit die totaal van 61 keer wat die NT dit gebruik. Lukas gebruik dit 17 keer in sy twee boeke en Paulus 19 keer. Weer eens vind ons dit glad nie by Johannes in sy Evangelie of in sy briewe nie.

In 'n hele aantal gevalle word kērussein gebruik saam met euangelion as voorwerp (Mat. $4: 23 ; 9: 35 ; 24: 14 ; 26: 13$; Mark. $1: 14 ; 13: 10 ; 14: 9 ; 16: 15$; Gal. $2: 2$; Kol. $1: 23 ; 1$ Tes. $2: 9$ ). Saam met basileia as voorwerp word dit ook vier keer gebruik (Luk. $8: 1$; $9: 2$; Hand $20: 25 ; 28: 31$ ). Daar word 9 keer gesê dat Jesus verkondig word (Hand $8: 5 ; 9: 20 ; 10: 42$ as regter; $19: 13 ; 1$ Kor. $1: 23$ die gekruisigde; $15: 12 ; 2$ Kor. $1: 19 ; 4: 5$; vgl. ook 11:4; Fil. $1: 15)$.

\section{DIDASKEIN}

Didaskein word 97 keer in die NT gebruik. Daarvan is 58 keer in die evangelies en 16 keer in Handelinge. Jesus is in die evangelies die Een wat onderrig. Die werkwoord word daar omtrent 50 keer gebruik waar Hy die subjek is. Byna sonder uitsondering word die inhoud wat Hy onderrig nie vermeld nie. 'n Uitsondering is Luk. 11:1 waar Hy versoek word om die dissipels te leer bid. In Handelinge is dit veral die apostels maar ook ander soos Apollos (18:25) 
wat onderrig. Anders as in die geval van Jesus word hier dikwels gesê wat die inhoud is wat onderrig is: Jesus Christus (Hand. 5 : 42); die woord van die Here $(15: 35)$; die woord van God (18:11); die dinge van Jesus (18:25); die dinge van die Here (28:31).

\section{EUANGELIZESTHAI, KERUSSEIN, DIDASKEIN SAAM GEBRUIK}

Euangelizesthai en didaskein word saam genoem in Lukas 20:1, Hand. $5: 42$ en $15: 35$. Kērussein word saam met didaskein gebruik in Mat. $4: 23 ; 9: 35 ; 11: 1$ en Hand. $28: 31$. Hierbenewens word kērussein en euangelizesthai saam gebruik in Luk. $4: 18 ; 8: 1$. Uit hierdie gebruik is dit duidelik in hoe 'n mate die woorde dieselfde handeling aandui. Friedrich (ThWNT II : 718) sê dat dit skyn asof die frase kērussoon kai euangelizomenos tēn basileian tou Theou (Luk. 8:1) 'n omvattende beeld van die hele optrede van Jesus gee.

Wanneer 'n mens die drie woorde dieper deurgrond, blyk dat euangelizesthai aan ons die wat wil gee sonder die hoe. Dit sê dat die handeling wat verrig word, is om Christus te bring an mense wat nie in Hom glo nie. Kërussein sê dieselfde maar bring daarby iets van die hoe uit. Dit word gedoen as 'n kragtige aankondiging, as 'n proklamasie in opdrag, as gesaghebbend. Didaskein (om te onderrig) roep die beeld van die didaskalos (die onderwyser) na vore. Dit sê dus iets anders van die hoe naamlik soos 'n onderwyser aan sy leerlinge, deur verduideliking en beelde, deur vergelyking en verstaanbaar maak van feite, deur meedeling van kennis wat nie bekend was nie. Die onderrig van die Joodse rabbi is die beeld wat hier opgeroep word.

DIE WOORDGROEP MARTUS (getuie), MARTUREIN (om te getuig), MARTURIA, MARTURION EN DIAMARTURESTHAI

\section{Martus (getuie)}

Strathmann (ThWNT IV : 489 en verder) gee 'n goeie beskrywing van hierdie woorde. 'n Getuie is oorspronklik in die algemene sin iemand wat kan praat uit eie direkte kennis (Mark 14:63, Mat. $26: 65$ ). Die gebruik wat Lukas maak van die woord in Luk. $24: 48$ en Hand. $1: 8$ bring ons egter naby euangelizesthai. Hier sê Jesus: "Julle is my getuies..." en "julle sal my getuies wees ...." Die betekenis is hier steeds dat iemand slegs verkondig wat direk aan homself bekend is. Die feite wat so verkondig word, is geskiedenisfeite. In die sentrum was hier die opstanding. Saam met die verkondiging gaan egter 'n dringende appél dat die feite erken moet word in geloof. In die getuienis is daar 'n onlosmaaklike verbintenis tussen die verkondiging van feite en die geloof daaraan en belydenis daarvan. Getuies is mense wat dit wat hulle verkondig beleef het en geroep is om getuies te wees (Luk. $24: 47$; Hand. $1: 8 ; 22-26$ ). Getuies het ook die nodige toerusting vir die taak ontvang (Luk. $24: 48,49$; Hand. $5: 32$ ).

Die getuies getuig deur die feite en hulle betekenis, soos hulle dit in die geloof aanvaar, te verkondig. Die reddende betekenis van die feite, veral die opstanding wat die getuies verkondig, is deur hulle beklemtoon (Hand $10: 42$ ). Alleen 'n beperkte kring het hierdie taak gehad. Hulle is volgens Paulus getuies by die volk (Hand. 
13:31). Maar Paulus noem homself en Barnabas nie hier getuies nie. Hy sê dat hulle besig is om te euangelizesthai (Hand 13:32). Paulus maak hier 'n onderskeid. Hy en Barnabas is nie getuies wat eerstehandse kennis verkondig in die sin wat die ander apostels dit doen nie. Tog gebruik Paulus die woord getuie in Hand. 22:15 en 26 : 16 van homself. Hier is veral 'n verwysing na Paulus se ervaring op pad na Damaskus. Hy is getuie omdat hy daar persoonlik Jesus ontmoet het. So is hy ook getuie omdat hy latere direkte openbaringe ontvang het.

Stefanus is ook 'n getuie (Hand 22:20). Hy sterf omdat hy 'n getuie vir Christus is en besig is om te evangeliseer. By hom is daar nie meer die betekenis dat ' $n$ getuie self kennis saam met Jesus moes opgedoen het nie. Hy is getuie omdat hy die kennis wat hy van daardie eerste getuies ontvang het, getrou oordra.

By Paulus en Stefanus het ons dus al 'n oorgang in die woord martus. Soos hulle by die ander die feite hoor en dan daarmee evangeliseer, so word die hele kerk getuies.

\section{Marturein}

In die Evangelie volgens Johannes en in sy eerste brief verwys hierdie woord uitsluitlik na Jesus, na sy Persoon en betekenis. Die inhoud van die getuienis is dat Hy die Seun van God is (Joh. 1:34). Met die oog hierop word getuig dat Hy ewig is (Joh. 1:15), dat die Vader Hom gestuur het (Joh. $5: 36 \mathrm{vv}$ ) ens. In die getuienis word gesê dat die Vader die ewige lewe in Jesus gee (1 Joh. 5:10 vv). Om vir Jesus te getuig, beteken altyd om Hom te verkondig as sootēr tou kosmou (Joh. $4: 42$ ).

So word getuig deur die Skrif (Joh. 5:39), Johannes die Doper (Joh. $1: 7,15,32,34 ; 3: 26 ; 5: 33$ ), God (Joh. $5: 32,37 ; 8: 18$ ), deur die werke wat die Vader Jesus gegee het om te doen (Joh. $5: 36 ; 10: 25$ ), deur Jesus Self (Joh. $5: 31 ; 8: 13$ vv. 18). As Jesus Self nie meer op die aarde is nie, getuig die Gees van die waarheid (Joh. 15:26; 1 Joh. 5:6). Ten slotte word die getuienis gegee deur die dissipels self (Joh. 15:27; 1 Joh. 4:14). Hulle getuienis is belydenis. Marturein en homologein smelt in mekaar in hulle getuinis (1 Joh. 4:14 vv). Die persoon wat maar net 'n getuie sonder geloof is, is eintlik geen getuie nie. Hy sien niks van die heerlikheid van Christus nie. Alleen aan die gelowige word sy heerlikheid geopenbaar (1 Joh. 5:9 vv). Deur hierdie geloof kan daar dan nuwe getuies kom soos Paulus in 'n sekere sin, en Stefanus.

\section{Marturia}

Uit die 30 keer wat Johannes die woord gebruik, wys 27 keer na Christus se Goddelike herkoms en die doel is om diegene tot geloof te bring wat die getuienis hoor. In Joh. $21: 24$ beskryf Johannes homself as getuie en sy getuienis, dit is sy hele Evangelie, het die doel wat hy in 20:31 noem. In Joh. 5:9-11 word van die getuienis van God wat identies is aan die getuienis van die Gees melding gemaak. Die inhoud van die getuienis is dat God die ewige lewe aan ons gegee het en hierdie lewe is in sy Seun . 


\section{In die Skriflig}

\section{Marturion}

Hierdie woord word slegs in Openbaring gevind sover dit die geskrifte van Johannes betref. Dikwels word dit gebruik in die sin van getuienis teen iemand wat hom skuldig bewys. Slegs Lukas gee 'n ander betekenis hieraan naamlik in Lukas 21:13. Hier beteken marturion dieselfde as euangelion, kērugma of didaskalia. So word dit ook gebruik in 1 Tim. $2: 6$.

\section{Diamarturesthai}

Hierdie woord word o.a. in Hand $20: 24$ gebruik waar gesê word dat Paulus in sy bediening kragtig getuig het vir die evangelie van God. Die koninkryk van God (Hand. 28:23), die Woord van die Here (Hand $8: 25$ ) is die dinge wat so met klem betuig word. In Hand 20:21 lees ons dat Paulus so by sowel Jode as Grieke getuig het en daarmee aangedring het op bekering tot God en geloof in Jesus Christus.

\section{DIE INHOUD VAN KERUGMA, EUANGELION EN MARTURIA}

Ons het reeds in verband met euangelizesthai gesien dat dit Christus is wat meegedeel word. Die inhoud van die prediking waarmee ge-evangeliseer is, moet egter nader aangedui word. In die woordgroep martus ens het geblyk dat die opstanding 'n sentrale plek inneem in die verkondiging. Paulus gee in 1 Kor. $15: 3-8$ die volgende elemente: die sterwe van Christus, sy begrafnis, sy opstanding op die derde dag, sy verskyning as bewys van sy opstanding. Groot klem word hier gelê op die historiese betroubaarheid van die opstanding. Uit Hand $17: 22-34$ weet ons dat daar nog drie elemente in die eerste prediking bygekom het, naamlik dat God Skepper is, dat die mens nie sy roeping vervul het nie en dat Jesus wat opgewek is, kom om te oordeel. Die verkondiging dat God Skepper is, gee vir Paulus 'n aanknopingspunt by die heidene. Petrus het in sy prediking in Hand 2 by die OT aangesluit omdat hy vir Jode gepreek het. Hy wys egter hoedat die OT Jesus verkondig. In die verkondiging is ook altyd God se beloftes en eise ingesluit (Stott, $1981: 56$ ).

Die prediking waarmee volgens die NT ge-evangeliseer is met die doel om oor te bring van ongeloof na geloof was eenvoudige prediking. Enkele hoofsake is skerp omlyn om sodoende die ongelowige sy eie posisie beter te laat verstaan en hom tot redding te laat kom.

\section{APOSTELLEIN, MATHETEUEIN EN DIE SENDINGBEVEL}

Die sendingbevel word gegee in Mat. 28:19; Markus 16:15; Lukas $24: 47-48$; Joh. $20: 21$.

Markus beskryf die taak van die dissipels of apostels as kērussein to euangelion. Hieroor het ons reeds gehandel. Dit beteken dieselfde as euangelizesthai. Lukas skryf in die passief kēruchthēnai epi too onomati autou metanoian eis afesin hamartioon eis panta ta ethnē. Dit is duidelik dat ook Lukas die verkondiging van die woord wat geglo word en redding bring, sentraal stel .

Johannes sê dat Jesus sy dissipels stuur soos die Vader Hom gestuur het. Die opdrag wat uitgevoer moet word, word nie hier 
genoem nie. Uit Johannes se geskrifte verder kan ons egter met sekerheid sê dat die taak was om te getuig sodat mense kan glo en die ewige lewe kan hê. In die brandpunt is dus ook hier die verkondiging wat oorbring van ongeloof na geloof (Joh. 20:31).

Matteus sê egter dat die taak wat uitgevoer moet word, is om dissipels te maak, te doop en om alles te onderrig wat Jesus beveel het. Die NT-geskrifte is eenstemmig dat ' $n$ dissipel iemand is wat 'n persoonlike verbintenis het met die een wat hy volg en dat hierdie verbintenis sy hele lewe stempel en vorm. So 'n dissipel laat geen twyfel oor die een van wie die krag uitgaan wat sy lewe vorm nie (Rengstorf, ThWNT IV: 441). In 28 uit die 30 gevalle beteken mathētēs in Handelinge eenvoudig dieselfde as Christen.

Die woord sending kom van die daad van God af wat sy Seun stuur en die daad van sy Seun wat sy dissipels stuur. Dit is duidelik uit die opdrag in Matteus en Johannes. Die taak wat verrig moet word in die sending is om dissipels te maak. In Mat. 28:19 sluit mathēteuein die doop en onderrig in. Maar tog lê hier in mathēteuein ook iets ingesluit wat as vanselfsprekend aanvaar word, so vanselfsprekend dat dit nie genoem word nie, naamlik euangelizesthai. Hierdie element is so sentraal (Bosch, $1979: 21$ ) dat die twee evangelieskrywers Markus en Lukas die lig hierop skerp laat val en nie eintlik melding maak van die sake daaromheen nie. Matteus sien die sending dus as wyer as net euangelizesthai. Terwyl die taak begin by evangelisering moet die ongelowiges gebring word tot volledige dissipelskap. Hulle hele lewe moet gestempel wees deur Christus.

Ons moet die sendingbevel só weergee: "Nadat julle dan uitgegaan het, maak dissipels . . terwyl julle doop . . . terwyl julle onderrig". Ons kry hier eers 'n aoristus participium wat gelyk is aan die volgende aoristus imperatief (poreuthentes - gaan uit; en mathēteusate - maak dissipels) wat dan gevolg word deur twee praesens participia baptizontes - dopende, en didaskontes - onderrigtende). Die aoristi bring die hoofhandelinge skerp uit. Dit beteken dus dat die dissipels moet gaan en dat hulle elke keer weer dissipcls moet maak. Dissipels maak, beteken hier ten eerste deur te evangeliseer en nie soos Versteeg (1981:13) en Grosheide (1954: 454) sê deur te doop en te onderrig nie. Doop en onderrig word genoem as die dinge wat steeds saamgaan met die hoofsaak van dissipels maak of euangelizesthai. Alleen as ons so in mathēteusate hoofsaaklik euangelizesthai ingesluit sien, kan ons verklaar waarom Matteus hier onderrig na doop noem. Dissipels maak laat reeds die lig val op die positiewe gevolg van evangeliseer. So word die twee woorde ook in Hand. 14:21 saam genoem.

Dit bly dan egter 'n feit dat Matteus hier doop en veral die leer om alles te onderhou bybring by die werk van dissipels maak nl. om die Woord te verkondig. Daarmee toon hy aan dat die sending wyer gaan as net evangeliseer (Bosch, 1979:21, Van der Walt, 1981:1). Die Sendingwetenskap is dus ook wyer as die bestudering van evangelisering (Verkuyl, 1975:19). Dis egter nie reg om evangeliseer te gaan verbreed tot sending soos Verkuyl stel nie (1978:19). Sending sluit evangeliesering in as sy eintlike kern, maar is meer as dit. Evangeliseer sluit nie net die verbale in nie (so Verkuyl, 1978 
: 19) maar is die verbale. God se finale openbaring tot ons redding is die openbaring wat deur die woord (verbum) aan ons meegedeel word.

\section{ELENCHEIN, PARAKALEIN EN "EVANGELISASIE" EN "EVANGELISTIEK"}

Weens die verkeerde gebruik van die woord Evangelisasie en Evangelistiek is dit nodig dat ook aandag aan die twee Griekse woorde elenchein en parakalein gegee word. Hulle val nie in die groep wat positief die handeling is om van ongeloof na geloof te bring nie. Hulle bestraf of vermaan oor die negatiewe, die verkeerde reaksie teen die evangelie.

Van elenchein is die naam van die teologiese dissipline Elenktiek afgelei. Dit word omskryf as die wetenskap wat hom besig hou met die bestudering van die nie-Christelike religies, probeer om hulle diepste grondmotiewe te deurgrond en hulle tot verantwoording te roep in die lig van die openbaring van God in Christus (Bavinck, Christelijke Encyclopedie 2:580). Hierdie naam gaan gedruk onder baie besware.

Die werkwoord elenchein word 17 keer in die NT gebruik. Die eerste keer wat dit gebruik word, is in Mat. 18:15. Hier is dit uit en uit 'n saak van binne-kerklike bestraffing. Vervolgens word die bestraffing van Herodes deur Johannes die Doper met dié woord aangedui (Luk 3:19). In Johannes $3: 20$ is dit die wat boosheid doen wat bestraf word in die lig. In Johannes $8: 46$ vra Jesus wie Hom oor sonde kan bestraf. In Johannes $16: 8$ is dit die Heilige Gees wat die wêreld bestraf oor sy sonde.

Paulus maak melding van 'n ongelowige en onkundige wat inkom in die samekoms van gelowiges en deur hulle bestraf word deur profesie (1 Kor. 14:24). (Dit kan omdat ook hý nie sonder openbaring was nie). In Ef. 5:11 word vir die gemeente gesê dat hulle nie gemeenskap moet hou met die onvrugbare werke van die duisternis nie, maar dit moet bestraf (vgl. 5:13). Vir Timoteus sê Paulus dat hy die sondaars in die gemeente voor almal moet bestraf (1 Tim. $5: 20$ ). Dis ook binne-gemeentelike bestraffing in 2 Tim. $4: 2$, Titus 1.: 9, $1: 13,2: 15$, Hebr. $12: 5$, Jak. $2: 9$, Judas 22 (as ons dié tekslesing aanvaar waar elenchein gebruik word) en Openbaring $3: 19$. In Judas 15 gaan dit oor die straf oor goddelose mense wat in die oordeel voor God kom.

Dis dus duidelik dat die oorgrote getal kere waar elenchein (om te bestraf) gebruik word, die onderlinge bestraffing in die gemeente bedoel is.

Net so is dit met parakalein (om te vermaan) in een van sy verskeie betekenisse. Dit is ' $n$ vermaning aan die gemeente (Rom. $12: 1$; 2 Kor. $10: 1$; Tes. $4: 1$; Fil. $4: 2$; Ef. $4: 1 ; 1$ Tim. $2: 1 ; 1$ Pet. 2:11, 5:1, 5:12; Judas 3). Paulus se medewerkers het dit in die gemeente tot taak (1 Tim. $5: 1,6: 2 ; 2$ Tim. $4: 2$; Titus $2: 6,15$ ). Hebreërs roep die gelowiges op om mekaar te vermaan $(3: 13$, $10: 25$ ).

Die NT het dus nie euangelizesthai gebruik vir die vermaning van die afgedwaalde of afwykende nie. Veeleer is woorde soos 
elenchein en parakalein gebruik. Hier is duidelik die aspek van tug met die woord op die voorgrond. Dis immers mense wat reeds geevangeliseer is en daarop positief geantwoord het, wat nou aangespreek word. Wie nog nie ge-evangeliseer is nie, moet ge-evangeliseer word.

Die babelse verwarring wat daar oor "evangelisasie" bestaan, het verskillende redes. Ten eerste word die woord gebruik nie in sy Bybelse betekenis nie. In die NT word dit gebruik vir sending. Dis die verkondiging waarmee 'n appél gemaak word op 'n ongelowige om tot geloof te kom. Verder word dit gebruik vir opbou in die gemeente, vir voortgaande verkondiging, vir vollediger dissipel-making. Dit word nie gebruik vir die terugbring van afgedwaaldes nie. Hier is elenchein veel meer gebruiklik - dus bestraffing van dié wat weet.

'n Tweede rede vir hierdie verwarring is dat geopereer word met 'n verkeerde kerk- begrip. Laat ons eers na die NT kyk. Kerk het daar drie betekenisse nl. samekoms in erediens ( 1 Kor. 11:18, 20, $22 ; 14: 19,33,34 \mathrm{vgl}$. Didache XIV, 1), die gelowiges van die plaaslike gemeente (bv. 1 Tes. 1:1) en al die gelowiges saam (bv. Mat. $16: 18)$. Die tweede betekenis is vir ons hier veral van belang. Almal wat nie in daardie groep, dit wil sê die plaaslike kerk, geval het nie, moes ge-evangeliseer word, tot geloof gebring word. Dis die vermeerdering van die kerk. Almal wat in daardie groep gedwaal het, moes bestraf, elenchein of parakalein word. Dis bewaring van die kerk.

Ons huidige situasie het egter tot stand gekom omdat daar verskille gekom het wat denominasionele mure gebring het. In plaas van een plaaslike kerk waarin al die gelowiges ingesluit is, het daar verskillende strukture (institute) gekom. Elenchein vind dus nou nie mecr plaas tussen al die gelowiges onderling binne die plaaslike gemeente nie. In plaas daarvan sien hulle mekaar as "evangelisasieobjekte" waarmee die eie denominasie vermeerder kan word. Dit is natuurlik hoegenaamd nie die vermeerdering van die kerk waarvan Heidelbergse Kategismus, Sondag 48, vraag en antwoord 123 praat nie. Die eie denominasie alleen word hier verhef tot kerk.

Weens hierdie onduidelikheid oor die betekenis van die woord evangeliseer en van wat die plaaslike kerk in die NT is, kry 'n mens dan onaanvaarbare definisies en word selfs 'n teologiese dissipline geskep wat nie bestaansreg het nie. De Klerk (1979:16) praat van "evangelisasie" van die "afvallige buitekerklike en kerkvervreemde bondeling". Dis dan sy derde kategorie van "evangelisasie-objekte". Die eerste twee is wat ek bo genoem het, die ongelowiges en die gemeente wat gebou word.

Wie is hierdie derde groep nou? Van der Walt (1981:3) sê dat hulle buite die kerk staan. Buite watter kerk? As dit buite die ware gelowiges is, is hulle heidene al was hulle in die verbond. Hulle is in laasgenoemde geval ongelowige verbondsverbrekers. Dan is hulle mense wat ge-evangeliseer moet word, by wie sending gedoen moet word. As hulle net buite die eie denominasie staan, is hulle nie voorwerpe van evangelisering nie, maar van bestraffing as 'n mens oortuig is dat jou eie belydenis reg is. Met groot klem moet gesê 
word dat die NT nie 'n grys gebied ken van mense wat tussen ongelowiges en gelowiges staan en waarmee die kerk vermeerder kan word nie.

Die opdrag van Mat. 28:19 is dieselfde tov. Jode en heidene. Die Jode wat nie in Christus geglo het nie, was verbondsverbrekers. Die heidene was nog nooit in die verbond nie. By albei gaan dit in die mathēteuein (wat euangelizesthai insluit) dáárom dat Christus aangeneem word. Die benadering in die uitvoering van die een sendingopdrag vir Jode en heidene was egter verskillend. Vir die Jode was die aansluitingspunt die OT. Vir die heidene was dit God se openbaring in die skepping, geskiedenis en gewete. Vanaf hierdie openbaring is daar beweeg na die helderder openbaring - die Woord.

Gevolgtrekking: Die taak van die kerk is eerstens om te evangeliseer en dan te bou en bewaar. ' $n$ Deel van hierdie tweede taak is om te bestraf of vermaan. Daar is nie 'n tussentaak "evangelisasie" nie. Elke plaaslike Gereformeerde gemeente moet alle ander mense of sien as mede-gelowiges en hulle probeer oorreed tot die volle waarheid en volle vrugte, of as on-gelowiges en hulle evangeliseer. Dit beteken dat ook alle lidmate van denominasies in die twee groepe ingedeel moet word. Die verbond (wat verbreek is) en 'n corpus christianum (Spoelstra, IDS Junie 1982:37) bring nie mee dat daar 'n afsonderlike groep bestaan wat afsonderlik bearbei moet word nie.

\section{HOE MOET GE-EVANGELISEER WORD?}

Wanneer ons die verskeidenheid woorde rondom euangelizesthai bestudeer, merk ons dat betreklik min oor die hoe gesê word. Die wat en die hoe is egter baie sterk aan mekaar verbind.

Die taak is gegee aan amptelike predikers en aan die hele gemeente (Floor, 35, 44-50). Dit geld sowel die evangelisering van die heidene as van die gemeente self.

Die hoe van die evangelisering kan die beste beskryf word vanuit 1 Kor. 9:16. Paulus sê dat die dwang hom opgelê is om die evangelie te verkondig. Dit beteken nie dat hy dit gedwonge doen nie, maar gedronge. Die liefde van Christus dring hom (2 Kor. 5 : 14; Rom $1: 16$ ) en die drang is ter wille van wie ook al sy evangelie hoor (2 Kor. $5: 20$ ). Hierdie innerlike drang word deur die hele NT weerspieël met uitsondering van mense soos Demas en ander wat in kleinlike eiebelang optree.

Waar kom die drang vandaan? Van die Heilige Gees (Hand. $1: 8$; Joh. 20:22; Luk. 24:49 ens). Die Heilige Gees dring elke ware gelowige om ook ander tot die geloof te laat kom en ander op te bou. Hy gee die gawes om op te bou (1 Kor. 12-14). Hy oortuig in die hart. In die Gees is Christus Self aan die werk. Hand $5: 32$ is hier baie belangrik: "En ons is sy getuies van hierdie dinge, en ook die Heilige Gees wat God gegee het aan die wat Hom gehoorsaam is".

Dis die Heilige Gees wat ook die parrēsia gee. Vir hierdie parrēsia het die apostels gebid (Hand $4: 29$ ). Ons lees van hierdie vrymoedigheid in Hand $2: 29,4: 13,4: 29,4: 31,9: 27,9: 28$, $13: 46,14: 3,18: 26,19: 8,26: 26,28: 31$. 
Die vrymoedigheid en die drang was die redes waarom die evangelie oral en altyd verkondig is: Terwyl die klippe reën op Stefanus (Hand. 7), toe die dissipels vlug (Hand. 8:4), dag en nag deur Paulus (1 Tes. $2: 9$ ).

Die verkondiging is egter soos die gebed. Die gebed is die vernaamste deel van ons dankbaarheid. As die gebed woorde sonder lewe, sonder dade is, word dit ydele, betekenislose, leë woorde. So is dit ook met evangeliseer. Juis om hierdie rede beklemtoon die Here dat die lewe moet bevestig dat ons dissipels is. Eerediens word maklik vormdiens (Jesaja 1). As die lewe nie toon dat daar liefde vir die naaste is nie, is die geloof nie daar nie. Jesus swyg oor erediens en verkondiging met die woord in Mat. 25, en oordeel op grond van die kos en water wat ons gegee het, die herberg, die kleed, die siekebesoek, die opsoek in die gevangenis. Hieruit blyk die geloof wat ons die koninkryk laat beërf. Dis ons lewensverhouding tot ons naaste wat hier so belangrik is. Evangeliseer hiersonder is leeg en dood en toon ' $n$ hart wat nie gedronge is nie. Wie nie omgee om sy naaste nóu te help nie, kan nie opreg gedronge wees om hom te help om die toorn van God te ontkom nie. Hy doen evangelisering as koue plig. (Natuurlik ag die Here nie erediens as onbelangrik nie. Maar as dit al vrugte van die geloof is, is dit vals).

'n Ander woord wat vir ons sê hoe ons moet evangeliseer, is Mat. $7: 29$ se hoos eksousian egoon (soos iemand wat gesag het). So het Jesus geleer. So moet elkeen kom wat met die Woord van die Here kom. Hy is 'n gesant van Christus (2 Kor. 5:20) en kom dus met die gesag van sy Sender.

Ons vind nêrens in die Bybel sistematiese metodes en programme om te evangeliseer nie. Dis eerder 'n geval van so 'n ryke verskeidenheid soos die lewe self waarin die gelowige telkens sy boodskap bring. Dit geld natuurlik veral vir evangelisering van ongelowiges. By verbondsverbrekers moet die klem op God se oordeel val hoewel met volgehoue liefde gewerk word. Dikwels is egter by die vorme van die sinagoge aangesluit, veral wat betref evangelisering as opbou van die gemeente.

\section{WAT DAN VAN "EVANGELISASIE"?}

Watter implikasies het die gevolgtrekkings wat uit hierdie studie gemaak kan word nou vir wat tradisioneel genoem word "evangelisasie"? Die volgende kan genoem word.

1. Onderskei tussen 'n persoon wat vermaan, bestraf of reg gelei moet word aan die een kant en 'n ongelowige. Eersgenoemde is nie buitekerklik nie al is hy in 'n sekte. Hy is ook nie 'n verbondsverbreker nie. Hy moet pastoraal bearbei word net soos iemand wat binne die eie denominasie dwaal. Die pastorale werk moet nie afgemuur word by die grense van die eie denominasie nie. As hy die gemeenskapsbelewing verbreek het met 'n gereformeerde gemeenskap moet hy kragtens die opdrag van die ouderlinge-formulier om die "boetvaardiges weer in die gemeenskap van die kerk te ontvang" bearbei word. $\mathrm{M} \mathbf{i}$ is daar geen ander teologiese dissipline no dig vir die bestudering van dié arbeid nie.

Verbondverbrekers word net soos die Jode in die tyd van Paulus 
ge-evangeliseer. Soos vir die heidene word by hulle aangedring om Christus aan te neem. Weens hulle kennis moet die klem swaarder val op die oordeel oor ongehoorsaamheid. Die NT sien nie evangelisering van Jode en heidene as twee verskillende aksies nie. Dis een hoewel die benadering verskil. Die prinsipiële eenheid lê daarin dat evangelisering wil oorbring van ongeloof tot geloof. Die klem val nie op verbondsherstel of inbring in die verbond nie, maar op geloof in Jesus Christus. Dit het natuurlik onmiddellik implikasies van of verbondsherstel of inkoms in die verbond.

2. Denominasionele mure is nie "kerk"-mure nie. Daar moet ondanks verskille ' $n$ groter aanvaarding van mede-gelowiges in ander denominasies wees. Daar moet 'n vryer gemeenskapsbeoefening wees en veel meer vrymoedigheid om oor die verskille te praat.

3. Die skerp snypunt is geloof of ongeloof. Ongehoorsame gelowiges (wat dwaal in leer of lewe) moet met die grootste liefde verdra en bearbei word as mede-gelowiges. As hulle nog in die eie denominasie is, is dit ' $n$ proses van tug wat voortgaan. Onttrek hulle hulle van die tug, moet die bearbeiding en tug deur medegelowiges steeds voortgaan hoewel hulle as gevolg van die verskeurdheid nie meer getug kan word deur die kerk soos die wat nie die band verbreek het nie.

4. Daar is geen verskil in die staat van ongelowiges wat wel en wat nie vroeër in die verbond was nie. Albei kategorieë is ongelowiges en moet deur evangelisering gelei word tot Christus. Alleen die benadering verskil - soos reeds aangedui. Paulus het vir die Jode in sy prediking aangesluit by die OT. Vir die heidene het hy aangesluit by die openbaring wat hulle gehad het.

\section{BRONNELYS}

Aland K. Red 1975-1981 Vollständige Konkordanz Zum Griechischen Neuen Testament, Walter de Gruyter, Berlin, New York.

Bavinck, J. H. 1957 Elenctiek in Christelajke Encyclopedie, Grosheide, F. W. en Van Itterzon, G. P. Red Vol. 2.

Bosch, D. J. 1979 Heil vir die Wereld, N G Kerkboekhandel, Pretoria.

De Klerk, J. J. 1979 Begripsbepaling in Evangelistiek, De Klerk, J. J. Red. N G Kerkboekhandel, Pretoria. 
Didache toon doodeka apostoloon. Loeb Classical Library.

Dodd, C. H. 1936 De Aposiolische Prediking en haar Ontwikkelingsgang, vertaal deur Dirkse-Bresters, H. C., G. F. Callenbach N. V. Nijkerk.

Floor, L. Die Missionêre Karakter van die Kerk, in Kerk en Wêreld, I. J. van der Walt en L. Floor, Calvyn Jubileum-boeke-fonds, Posbus 20004, Noordbrug. Friedrich, G. 19714 Euangelizesthai in Kittel, G. Red vertaal deur Bromiley, G. W. Theological Dictionary of the NT. Vol II, WM B. Eerdmans Pubishing Company, Grand Rapids, Michigan.

Friedrich, G. 19724 Kērussoo in Kittel, G. Red vertaal deur Bromiley, G. W. Theological Dictionary of the NT, Vol III, WM. B. Eerdmans Publishing Company, Grand Rapids, Michigan.

Gitari, D. 1975 Theologies of Presence, Dialogue, and Proclamation in Douglas, J. D. Red Let the Earth Hear His Voice, World Wide Publications, Minneapolis, Minnesota.

Grosheide, F. W. 1954 Het Heilig Evangelie Volgens Mattheus, N. V. Uitgeversmaatschappij, J. H. Kok, Kampen.

Rengstorf, K. H. 1973 Mathētēs ens' in Kittel, G. Red vertaal deur Bromiley, G. W. Theological Dictionary of the NT, VoI. IV, WM. B. Eerdmans Publishing Company, Grand Rapids, Michigan.

Schlier, H. 19734 Parrēsia ens in Kittel, G. Red vertaal Bromiley, G. W. Theological Dictionary of the NT Vol V, WM. B. Eerdmands Publishing Company, Grand Rapids, Michigan.

Schmitz, O. 19754 Parakeleoo ens. in Kittel, G. Red vertaal deur Bromiley, G. W. Theological Dictionary of the NT, Vol V, WM B. Eerdmans Publishing Company, Grand Rapids, Michigan.

Spoelstra, B. Bockbespreking (Van der Walt en Floor) in In die Skriflig, Jrg. 16, No. 62 Junie 1982 ,GTV Posbus 59 Hammanskraal.

Stott, J. R. W. 1981 De Bijbelse Grondslag van Evangelisatie, in Bouw, W. J. Red. Evangelisatie. Wat verstaan we er onder?

Strathmann, H. 19732 Martus ens. in Kittel, G. Red vertaal deur Bromiley, G. W. Theological Dictionary of the NT, Vol IV, WM B Eerdmans Publishing Company, Grand Rapids, Michigan.

Van der Walt, I. J. 1981 Inleiding tot die Teologie van Evangelisasie en die Evangeliserende Kerke in Kerk en Wereld, I. J. van der Walt en L. Floor, Calvyn-Jubileumboekefonds, Posbus 20004, Noordbrug.

Verkuyl, J. 1978 Inleiding in de Evangelistiek, Uitgeversmaatschappij, J. H. Kok, Kampen.

Verkuyl, J. 1975 Inleiding in de Nieuwere Zendingswetenschap, Uitgeversmaatskappij J. H. Kok, Kampen.

Versteeg, J. P. 1981 Opdracht in Viervoud, in Bouw, W. J. Red. Evangelisatie Wat verstaan we er onder? Uitgeversmaatschappij J. H. Kok, Kampen. 